\title{
Narrative as a Resource for Feminist Practices of Socially Engaged Inquiry: Mayra Montero's In the Palm of Darkness
}

\author{
LAURA GILLMAN
}

Against the view that the physical sciences should be the privileged source of reliable knowledge within the academy in general, and in philosophy in particular, this essay argues that an interdisciplinary approach to knowledge-production, one that includes social and psychological assessment as well as narrative analysis, can better capture the diverse range of human epistemic activities as they occur in their natural settings. Postpositivist epistemologies, including Lorraine Code's social naturalism, Satya Mohanty's and Paula Moya's postpositivist literary and pedagogical projects, and Linda Alcoff's dialogical template for knowledge form the basis of a revised naturalized epistemology that is more accountable to a socially engaged inquiry. This revised naturalism shifts orientation from the idealized setting of the laboratory and its a priori conditions for knowledge to localized settings, where knowledge emerges out of diverse contextualized interpretations of the natural and social world that interlocutors produce as they dialogue with one another. Mayra Montero's neocolonial narrative thematizes the spatial shift of scientific activity, showing how epistemic authority, aligned with North American interests and regional identity, is established, withheld from others, and contested.

The emergence of subaltern struggles in the last half of the twentieth century has generated the rise of resistance narratives on a global scale. Through the telling of stories, those classified as "other" disseminate perspectives that challenge prevailing worldviews on well-known events as well as raise awareness of the social problems facing marginalized communities (Stone-Mediatore 2003, 1). Narrative has also been characterized as a form of political expression fueled by epistemological concerns. Through the characters' struggles to know, the reader learns how people acquire and use knowledge to set strategic priorities. Seyla Benhabib conceives of narrative as an account of the self that all people construct. Although the norms informing our accounts correlate with "expectable and understandable biographies and identities in 
our cultures," subaltern subjects produce new stories of their identities in order to emancipate themselves from distorted "historical" accounts, thereby positioning themselves as "author and character at once" (Benhabib 1992, 214). Nonetheless, as Barnor Hesse notes, because of power asymmetries produced by hierarchical structures of racism, sexism, and classism, the value of a minority community's cognitive systems becomes obscured to its members, diminishing the likelihood that they use such systems as a context for identification with their historical community and reconnection with its values and knowledge practices (Hesse 2000, 115).

Though adopted across the academy, narrative knowledge remains identified with folk knowledge rather than with the logical arguments of scientists, and is consequently viewed as having anecdotal value. In orthodox, Western, philosophical academic epistemology, for example, conclusions about objective knowledge are presented in propositions and verified by appeals to observational data. The knowledge-producer is an individual, separately accountable to the evidence, whose methods must be replicated by other individual knowers in order to count as knowledge. Knowledge is patterned after physical knowledge, and science is its source. To ensure objectivity, scholars must show detachment from emotions, values, and interests to eliminate bias (Jaggar 1983, 345; Code 1993, 17-19; Tanesini 1999, 42).

In this essay, I argue that narrative knowing ought to serve as a privileged methodological instrument across the disciplines, especially in classic epistemology. Rather than enhancing propositional knowledge, narrative knowing operates pedagogically by exposing the knowledge-producer to situations that show knowledge to be tied to historically and culturally specific meanings. Narrative knowledge is aligned with what Susan Babbitt calls nonpropositional understanding. Narrative knowledge-practice asks the knowledge-producer to detect new sets of relations in order to render intelligible those aspects of the world that had previously been obscured, allowing the inquirer to change his or her entire perspective (Babbitt 1993, 258). This process of "connecting the dots" can facilitate nonexploitative social inquiry.

Developments in recent decades within traditional analytic epistemology, literary criticism, and feminist thought have contributed to the elaboration of new theoretical accounts of knowledge that allow for further development of the narrative paradigm. The "narrative turn" in the academy offers a view of knowledge that takes social causes into account in the inquiry process. It has resulted from an incipient awareness that narrative illuminates the discontinuity between subaltern people's narratives of their experiences and the governing theories or "stories" that attempt to explain and know them better than they know themselves. ${ }^{1}$ Insofar as they provide the background of understanding against which subjects interpret their experiences as well as form reasons for their actions, stories can potentially map the processes by which certain kinds of knowledge come to prevail as legitimate, that is, become theoryshaping, while others do not (Code 1998, 205; Richards 2001, 315-21). In what follows, I analyze the novel In the Palm of Darkness by Cuban Puerto-Rican Mayra Montero as a meditation on narrative knowledge derived from Western scientific paradigms. The reader begins to conceive of scientific knowledge as narrative when witnessing the protagonist's encounters with other characters-women and people of 
color-who espouse competing and often incompatible narratives. In my analysis, I draw upon two frameworks on narrative knowledge, postpositivist realism and feminist naturalized epistemologies, both of which offer a view of subaltern identities as potentially privileged sites for the production of genuine knowledge of the social world.

\section{The Metaphor of the "Survival of the Fittest"}

Montero's In the Palm of Darkness makes central the influence of scientific inquiry on social relations linked to imperialist and nationalist projects in the Caribbean, in particular, those derived from Darwinian evolutionary theory and Spencerian positivism, as well as the effects of social relations on scientific practices. Her oppositional narrative uses a variety of literary and rhetorical devices that call attention to how scientific method constructs "objective" reality in order to serve the interests of particular knowers. These include irony, metaphor, and metalepsis. Irony is a device that produces incongruity between what is expected and what actually occurs. Irony here issues from the reader's ensuing awareness of the unreliability of the protagonist/ narrator, exposing contradictions in the protagonist's cognitive schemas. I define metaphor here as a discursive mechanism that encapsulates the background assumptions informing the protagonist's sense of reality. I focus on one metaphor: "survival of the fittest." Metalepsis is a metafictional device that questions long-held ontological assumptions, namely, that the narrator and reader live in a different world than the characters, and are therefore not held captive to its rules or dilemmas (Fludernik 2009, 100).

Montero's novel contains two intersecting threads: the private life of the protagonist and his professional quest. In 1992, Victor Grigg, North American herpetologist, determining that his wife has left him for another woman, accepts his senior colleague's invitation to travel to Haiti. His mission is to capture the one remaining specimen of the grenouille du sang (the "blood frog") on the Mont des Enfants Perdus. Upon his delivery of the specimen, his colleague will breed the species in the laboratory in order to avert its extinction. Grigg's arrival coincides with the forced exile of President Aristide, during which time the tonton macoutes, the thuggish attachés of the military regime, are crushing popular opposition and reinstating their drug trade. Grigg retrieves the frog with the help of his local guide, Thierry Adrien, amateur frog-hunter, vodou priest, and pwazon rat (zombie-hunter). Nonetheless, Grigg's efforts to compensate for the "extinction" of his masculine status, resulting from his wife's apparent changed sexual orientation and infidelity, by augmenting his professional status, are thwarted. Grigg drowns when the ship he and Thierry board to return to Port-au-Prince sinks.

Grigg's relentless efforts to avert anuran extinction are puzzling to the reader in light of this anticlimactic ending. His professional activities emphasize his exemplary role as sensory or information processor, capable of rendering empirical data about the laws governing nature. Yet they tell us next to nothing about the meaning or the 
utility of the research. The truncated ending obliges the reader to ask what remains unanswered: Why is the survival of the blood frog so important to Grigg? What led to his wife's infidelity? Why does he not talk to her about it? The reader is forced to look more closely for clues in background data within the narrative structure to reconstruct the story.

The irony that often inheres in first-person narrations results from the reader's exclusive reliance on the narrator for "truth-telling." Gradually becoming aware of Grigg's narrative unreliability, the reader is obliged to consider the horizon or background for Grigg's outlook and self-concept, derived from his social location, and how that background causes him to formulate the epistemic relevance of his experiences. As his story develops, it becomes clear that Grigg is able to congeal his firstperson narrative by utilizing a story or metaphor that assumes that the social world is guided by the same types of mechanistic laws governing the amphibians he studies. These laws are derived from Darwinian science and positivist scientific inquiry. Accordingly, the social world, as well as the natural, is one of competition. In both arenas, the adaptation, variation, and survival of organisms occur as a consequence of struggle. The metaphor of "survival of the fittest," as designated by proponents of social Darwinism, elaborates the concept of struggle as the outcome of a contest between social groups, cementing the idea that human nature is continuous with animal psychology (Novoa and Levine 2010, 9). Although the term fit literally referred to the organism's adaptation to its environment, it has been used figuratively to signify superiority of whites over nonwhites. It has also been used to justify asymmetrical power relations based on gender (Stepan 1986).

In a literary context, metaphor refers to the comparative use of figurative speech. The narrator or character uses figurative language to draw a comparison between objects or situations. Narratologist Monika Fludernik affirms that a metaphor develops in narrative when an implied narrator or character substitutes an object or a situation for another in order to reveal some of its intangible aspects (Fludernik 2009, 74). But she goes further to suggest that metaphor refers to the background logic of the overall symbolic/narratological structure (74). Here, Fludernik begins to offer a conceptualization of metaphor that resonates with its articulation within the philosophy of language and the philosophy of science. Edward Schiappa argues, in his analysis of the epistemic status of rhetoric, that master tropes such as metaphors are not only literary devices used to embellish, but function in all discourse as mechanisms for making sense of reality. It should therefore not be surprising that metaphors form the basis of scientific discourse (Schiappa 1993, 404). As devices that cause the scientist/scholar to understand an object in terms of some other object, metaphors organize relationships between things, thereby producing new perceptions. Schiappa notes that philosopher of language Kenneth Burke uses the term perspective as an equivalent to metaphor, whereas philosopher of science Thomas Kuhn equates metaphor with paradigm (403-04). Schiappa further notes that paradigms are constituted by two elements informing the worldview of scientists: a complex of symbolic systems, norms, and models for knowledge-production that all practitioners in the discipline share; and exemplars, which are their applications. In the physical sciences, 
these paradigms or metaphors are either mathematical formulas or more ordinary language. Schiappa gives the example of the latter with the phrase "survival of the fittest" (404-05). Once the metaphor is learned through the symbolic representations of an exemplar, it is treated as a general view of reality (405).

The phrase "survival of the fittest" does not appear in Montero's novel as actual words in the text. Nonetheless, I suggest that it is an unspoken metaphor that undergirds the backgrounded cognitive/ideological logic of the text informing the character's view of reality. In identifying the metaphorical logic of the text, the reader gains insight into the models of knowledge informing that logic, the norms for the production, regulation, and justification of those models, and their symbolic structure, that is, the narrative account of their development. By retracing the metaphor in the character's actions, the reader can detect how it produces the sense-making mechanisms driving the character's desires, such as the survival of the blood frog. The reader can also understand Grigg's symbolic structuring of the world, including who he believes himself to be in relation to others as well as what beings or specimens are most valuable and therefore worthy of survival.

Postpositivist realist literary critic Satya Mohanty offers a view of narrative, which he links to identity, that resonates with philosophical conceptions of metaphor. In contradistinction to the positivist conception of a nonmediated, transparent objective reality, or the postmodernist conception that denies the human subject access to the world "out there," Mohanty suggests that experience, as a building block of identity, is a mechanism for knowing the world. But "knowing the world" is necessarily a theory-dependent process that can yield both accurate and erroneous evaluations. Arguing against the tenets of epistemological foundationalism, with its universalizing theories of justification, Mohanty turns to naturalized epistemologies, as espoused by W. V. O. Quine, to argue that genuine social knowledge can be produced when we "examine the production, justification, and regulation of belief as social processes" (Mohanty 2000, 31-32). Following Sandra Harding, Mohanty also highlights the theoretical assumptions that inform social processes. The notion of "women's lives" is a theoretical construct or narrative of women's experiences. But it also refers to gendered arrangements, including women's relationship to the world and to themselves. Women's standpoint is not a transparent rendering of experience. Rather, it is achieved when women make sense of their experiences by evaluating gendered arrangements in terms of their own interests. In doing so, they illuminate how processes that give rise to gender stratification are produced, regulated, and justified, as well as who benefits from these processes (39-43).

Grigg offers an interesting case study of the difficulties that a person with white, Western, male privilege faces when attempting to produce knowledge in the scientific realm, while at the same time divesting scientific knowledge from social processes. In denial of how his own background assumptions inform his interactions and thought processes, he is quick to highlight his own superior status as knower, as he explains early on when considering the scientist's solipsistic method, the "predict, observe, modify loop." He puts it thus: "When you're in a profession like mine, it's very easy to catch certain signals, identify certain odors, recognize the movements that announce 
imminent amplexus (the term used for sexual congress between frogs)" (Montero 1997, 2). His apparent sensory knowledge or sensory mastery also justifies his disbelief when it comes to what other people might do. He competitively asserts his own identity as superior in his interactions and dialogue with others. Yet the reader cannot fail to take into account other data that discounts his sensory superiority. There is no data in the context, for example, that would confirm his wife's "sexual congress."

As critical readers of Montero's novel, we cannot help but note Grigg's reticence to engage in dialogue or self-reflection. Grigg does not communicate with potential or real rivals. He does not discuss his work nor his wife's apparent infidelity or lesbianism with her, and he limits his discussion of frogs with Thierry to simple orders. Rather than confirming or disconfirming his beliefs, he manipulates the facts by suppressing information that does not fit his hypothesis. Grigg's competition and rivalry is first displayed in his interactions with his wife Martha, a marine biologist. Grigg explains that they made a decision before marrying to choose different scientific fields, or what Martha terms the "division of fauna," apparently to avoid competitive interaction (Montero 1997, 7). But their subsequent interactions reflect the precarious nature of such a tactic. They both create incomplete narratives in order to serve their respective interests. Grigg, for example, states that because of his developed sensorial knowledge, he knows that Martha is traveling with Barbara to India but refuses to ask Martha before he departs to his Nashville conference. He concludes that his wife has left him for Barbara because 1) the two women traveled to Dharmsala where they had planned to go when they first married; and 2) the coat that she was wearing upon her return, made from the wool of the blue sheep or so Martha says, was a gift from Barbara.

Rather than testing his theory by getting evidence or by critically reflecting on his background assumptions regarding his perspective of Martha as traitor and deceiver, he takes his belief as truth. The reader is obliged to reexamine Grigg's "evidence," given Grigg's description of the coarseness of the coat (a coat made from the wool of the blue sheep should be soft), and the few facts that we do know about Grigg and his wife. Intently motivated to succeed in Nashville to compensate for his perceived rejection, he fails to consider that professional jealousy, competition, and rivalry are what motivate Martha. Indeed, she plans the travel itinerary to coincide precisely with his, or as she says to him, "your conference"” (Montero 1997, 3). Whereas Martha does leave Grigg information about her whereabouts, he gives no information to Martha about his interview with Patterson in Nashville, nor about his plans to go to Haiti. He refrains from asking Martha about her trip because, he says, "an explanation would only be humiliating for me" (3). Grigg refused to share news about the conference with Martha, even when she began to interrogate him insistently, inciting his rivalry by mentioning his competitor, a real historical scientist:

She knew the allusion to Corben touched certain coiled springs of memory, memory and rivalry, things that are sometimes confused in the heart of a frog hunter, a researcher who wants to get there first, get in the first shot, before anybody else. She was trying to find out 
what had happened in Nashville, and to do that she would play dirty, root through my jealousies, search out my petty disappointments and failures. Corben was a genius who had been lucky. (6-7)

Later in the narrative, following Grigg's beating at the hands of the Haitian military police, Grigg appears defeated by what he believes is a love triangle. In his hotel room, in a delirious state, Grigg's unconfirmed suspicions reemerge, uncontained behind his mask of scientific authority. He refuses to submit to a vodou water ritual that Thierry wants to perform with him to heal Grigg's psychic woundedness, evident in his obsessive search for the frog. Instead, Grigg succumbs to a fantasy in which he ascribes to Martha scripts of female deception that have dethroned his sexual dominance as male subject. Grigg's response to Thierry's invitation makes clear that Grigg's loss of his masculine status motivates his redoubled efforts to preserve his masculine status as knower: "My wife left me Thierry. I don't want to talk about water. When do you think we'll be able to climb the mountain?" (78). Grigg's compulsive behavior causes the reader to reconsider Martha's actions, and conclude that, if anything, Grigg has left her, without a word as to his whereabouts.

Grigg also situates himself as superior knower in his relations with Thierry. Rather than treating Thierry as a co-participant who can give him input because he is from that environment and had worked as an apprentice under another herpetologist, Wilbur Jackson, Grigg treats him as a subordinate. The master/slave relationship that Grigg establishes as the model for their interaction, one that prohibits dialogue among equals, is indebted to the colonial relationships established in Haiti with French rule. With its systems of dependency and complicity, the master/slave relationship foregrounds the logic of the metaphor of the "survival of the fittest," underscoring how power struggles produced out of imperialist projects and justified by racial and gender ideologies are continuously remapped onto other spatial-temporal contexts.

We find evidence of the master/slave model in Grigg's first meeting with Thierry. When Thierry silently ponders Grigg's sketch of the frog, Grigg assumes he is feigning knowledge of the specimen. However when Thierry takes the pencil and details further the specimen's features, with a smile of confidence on his face, Grigg remains silent, trying to "gain a few moments"-most probably considering how to re-establish the proper master/slave relationship (Montero 1997, 19). Grigg attempts to do so on the Mont des Infant Perdus. On the mountain, Thierry urges Grigg to retreat. They are at risk, Thierry affirms, since the tonton macoutes use the mountain to store drug shipments and will kill anyone who interferes with their business. He points to the skeletal remains of seven bodies as evidence. Grigg dismisses Thierry's concerns, taking as truth the ubiquitous power of his own status as a white, male, Anglo-American scientist: "Nothing very serious can happen to a man when all he looks for, all he wants, is a harmless little frog" (41).

Grigg eventually agrees to retreat to the camp, but because he sees social interaction as a contest between social groups, resulting in the "natural" selection of the "fittest," he perceives Thierry's advice as a threat. Thierry is killing Grigg just as much by telling him to leave the mountain as those who will kill Grigg if he stays. 
When Thierry tells Grigg, following his beating, that the macoutes are the masters of the mountain, and they do not want him there, Grigg views him, like Martha, as a traitor: "He walked out of the room, not making a sound, and I was reminded of Bengali servants in the movies, the ones who always end up stabbing their masters" (66). Grigg's scripting of Thierry becomes evident as they drive away from the mountain. When Thierry advises him that he heard the blood frog sing twice the night before, Grigg, who had failed to hear the frog's song, refuses to believe him, saying: "You should have told me so then" (48). Enraged, Grigg slams his hand against the steering wheel, and Thierry exits the vehicle.

Given the lack of information in Grigg's narration about the reasons for his antipathy toward Thierry, the reader must interpret the data strewn throughout Grigg's narrative that Grigg himself never analyzes. The background data indicate that Thierry's stories of his sexual exploits and his successes in frog-hunting mirror back to Grigg his diminished capacities as a superior racial, gendered, and sexed subject. Although Thierry extends his commitments to Grigg beyond the requirements of guide when nursing him back to health following his beating, Grigg finds Thierry intolerable. He vows he will replace Thierry because "some people just don't have the right chemistry and Thierry and I hadn't taken to each other” (46).

Because of Grigg's view of social and scientific practice as competitive struggle, he discounts Thierry's testimony. He distorts the status of the frog's survivability in a report that he subsequently mails to Patterson. Grigg's account becomes the historical account, given in the last page of the novel, in the format of a newspaper article. The journalist has used as his source the report that Grigg sent to Patterson, explaining how Grigg made a trip to the Mont des Infant Perdu "but failed to find a single specimen of the grenouille du sang," but that weeks later, on Casetaches Hill, he "carried out an extensive search, and captured an adult male, which, according to the scientist's notes, was the last of its species on earth" (182).

Linda Alcoff's analysis of the rhetorical elements of knowledge and Lorraine Code's work on dialogue can provide insight about the violent suppression that results from Grigg's interactions. Alcoff conceptualizes identity as an interpretive horizon or background for one's outlook, derived from one's social location. Resonating with the work of postpositivist realists, she argues that complexly mediated cognitive processes can develop when subjects that are diversely located within a shared social horizon engage in a conversation (Alcoff 1995, 17-18). In Code's ecological model of knowledge, good knowledge is derived from diverse sources, expressing the whole of the social and natural world. It requires that different interlocutors tell their understanding of a situation, thereby minimizing the possibility of dispensing with critical self-reflection on one's paradigms and practices. Dialogue is a corrective in a milieu where science has colluded, in its colonizing capacity, in the shaping of a narrative of the world organized hierarchically by race, class, and gender (Code 2006, 63-94).

Montero creates an oppositional narrative by foregrounding rather than reproducing cognitive/ideological mystifications through a rescripting of cross-cultural encounters between interlocutors within asymmetrical power relations. She thereby encourages the reader to assess the characters' competing narratives and interests, and 
to be cognizant of the significance of social location or, to put it differently, identity, as a source of mystification or potential knowledge. In Montero's novel, it appears that Grigg's dialogical attempts within his cross-cultural encounters remain truncated precisely because he refuses to reflect on his identity as the basis for social/ideological mystifications.

In contradistinction to his distrust and lack of dialogue in his encounters with Martha and Thierry, however, Grigg's interactions with Patterson, and to some extent, with fellow herpetologists, is based on the comfort of shared understanding. This is because of their common identity status as knowers. As noted previously, Kuhn posits a view of scientists as practitioners who literalize their symbolic/metaphorical representations through their continued use of them, converting them into a reality. Literalization occurs because scientists within their particular subfields have had similar educations, absorbed the same literature, drawn the same conclusions, and share the same goals, including the training of their successors. Communication is easy and full, with judgments unanimously supported. Competition occurs within a scientific community, but only to further elaborate the paradigm, thereby allowing the scientist to achieve elevation in status. Advancement further depends on attendance at conferences, access to publication drafts, and participation in formal and informal communication networks, including those contained in correspondence or in citations within works (Kuhn 1996, 176-94).

In her social naturalism, Code identifies the paradigm or metaphorical worldview of scientists with narrative processes, emphasizing the fact that such paradigms are not necessarily accurate. Because knowledge is not an individual discovery or possession but is causally relevant to and constitutive of the sociocultural contexts of understanding in which it is produced, it is necessary, Code argues, for the inquirer to reflect on how his or her own contexts of understanding inform the knower and the known. In her essay "What is Natural about Epistemology Naturalized?" Code explains how such self-reflection might be achieved. She asserts that naturalized epistemology, as developed by Quine, can be useful for this purpose because it recommends a shift away from ahistorical notions of reason and justification to the examination of perceptual experience. However, it continues to use empirical psychology as a model to demonstrate how the transformation from perception to cognition happens, thereby preserving the site of the laboratory as the privileged domain of knowledge-production (Code 2003, 182). In the process, it also preserves the social group that predominantly inhabits that site-white men-as privileged knowers (182). Code thus recommends a revised social naturalism that reconnects sensorial experience to the background social theories that inform the scientist's interpretation of experience, thereby signaling how the social location of the knowledge-producer drives his knowledge-production (Code 2003; 2006, 63-94).

Looking at Grigg's behavior through the lens of social naturalism, it becomes clear that Grigg's cognitive practices are informed by the background theories and/or practices of the scientific community to which he pertains, as well as the community's interests. For instance, Grigg unreflectively puts on display the full communication he enjoys with fellow herpetologists as well as his competitive edge within the 
predominantly white, male scientific community. Grigg fantasizes with glee as he waits silently in the bushes for his frog to appear. He was chosen to have dinner with Patterson at the Nashville conference over other herpetologists who "would have fought for the privilege of sitting at his table" (Montero 1997, 4). Over dinner, there was minimal conversation, because, as Grigg recalls, Patterson has "sheer contempt for colleagues who talked to him about anything but amphibians" (4). At the dinner, Patterson refrains from dialogue except to inform Grigg that if he were not dying of leukemia, he would pursue the blood frog himself. He asks Grigg to go instead, offering him, if his mission is a success, a two-year research fellowship. A superior professional status is clearly Grigg's primary motivation in his mission.

Although the reader is now questioning Grigg's epistemic status, suspecting it to be tied not to universal truth but to the interests of a particular scientific community, Grigg himself continues to take his epistemic superiority for granted, conducting activities in accordance with his symbolic structuring of the world. These include: recording and filing the names of specimens on small cards; taping and transcribing; catching and placing specimens in jars; listening to and/or taping their calls; reading scientific journals, such as the Frog Log, a real scientific journal; composing diary entries; and writing and mailing reports. These activities appear incongruent, however, in Montero's narrative, precisely because Grigg undertakes them amid the political turmoil of a military coup produced by the ousting of Aristide and the violent instatement of a provisional military-backed government that randomly killed between three to five thousand Haitians.

Montero creates irony around the metaphor of "survival" by decontextualizing scientific tasks ostensibly undertaken by scientists in the name of human needs and survivability of the species, including the human species. She thus disrupts what rhetoricians Patricia Dunmire and David Kaufer refer to as the content-context interdependencies that inform conventional (nonironic) situations and utterances. Montero achieves decontextualization by producing a scenario that causes the reader to weigh the scientist's abstract, lofty goals to ensure species survival against Grigg's pursuit of a species that is so obsessive that it causes him to disregard human suffering and death (Dunmire and Kaufer 1996, 357). Montero further extends her use of irony by emphasizing the contradictions that result from Grigg's reliance on scientific practices as a means to assert his superior identity status. Grigg is proud of his mission, but even more of his status as "the fittest," as a member of the Anglo-Saxon race. This status is linked to the narrative of manifest destiny. As a narrative of white Anglo-American dominance, manifest destiny legitimizes Grigg's intervention in the spaces of other countries in the hemisphere to secure the position of prominence of Anglo-American discovery. His actions mirror those of the U.S. government, which backed, or so Aristide himself and other Haitians affirmed, the military coup that had ousted Aristide, seeing in the liberation theologian another Fidel Castro (Farmer 2003).

Far away from his laboratory, those surrounding Grigg perceive his authority as delusional. When he informs the embassy that he will be in Haiti indefinitely, and requests that they include his correspondence in the diplomatic pouch because "[i]t wasn't just any correspondence, after all, but documents, notes, and photographs 
addressed to laboratories and universities," the embassy official appears unimpressed, advising Grigg that he will have to look into his request (Montero 1997, 58). When Grigg tells two uniformed men who have come to Grigg's hotel to inquire as to the purpose of his visit that he is a biologist in search of a frog, they appear indifferent. The men ignore his sketch and his three-month permit, advising him to terminate his visit in thirty days. When the macoutes ransack his tent on the Mont des Infants Perdus, they break his specimen jars and defecate on his scientific bulletin, the Frog Log. Thierry manages to salvage some unharmed jars. Grigg, however, is focused exclusively on salvaging the bulletin, which includes his own article on the disappearing specimen of the rana pipiens, the title of which remained invisible due to the "stain left by the turds" (44).

While Grigg remains ensnared within the confines of his own metaphorical worldview, Thierry fulfills a primary function in the novel to bridge divergent paradigms of death and survival of the modern world: the world of the African-derived belief system of vodou and the Western world of science. As scholars of the African diaspora have noted, the discourses of vodou and science are mutually constitutive, contingent parts of a single historical social relation of Atlantic modernity (Fernández Olmos 1997, 267-82; Palmié 2002, 64-77). Within the modernist trajectory of Haiti, vodou became an entrenched part of belief communities as a result of the Atlantic slave trade, when the French imported 800,000 Africans to "Saint-Domingue" over the course of the eighteenth century to work as chattel in cacao, coffee, tobacco, and sugar plantations (Palmié 2002, 58).

Narrations of Caribbean modernity, linked to the vodou belief practices of West Africa that Thierry invokes as he shares his family stories with Grigg, represent an alternative worldview to Grigg's Western scientific one, pressuring Grigg to reflect on his confidence in the self-authorizing metaphors of positivist science in terms of being accountable to human survival, producing reliable knowledge, or facilitating social progress. In attempting to perform the water ritual on Grigg, Thierry wishes to impart to him the knowledge that the gods or loas have revealed to dispersed Africans under conditions of displacement. The ritual allows the loas to enter the heads of believers and persuade them to return to a thought of origin. As Joan Dayan explains, under conditions of forced dispersal, the loas go under the sea, under the waters, to the now impossible-to-return-to place of Guinea, where they share space with the ancestors. To undergo the ritual is to remember one's life in and develop knowledge about one's connection to the past, to the dead, and to a historical community that has been fragmented (Dayan 1997, 16-17). ${ }^{2}$

Grigg, however, refuses to bridge his own worldview to Thierry's. He acknowledges Thierry's novice status as frog-hunter, but because of his obsessive efforts to preserve his superior identity status, he refuses to take seriously and therefore is unaware of Thierry's capacities as vodou priest and pwazon rat. Yet Montero does not allow the reader to easily dismiss Thierry, as Grigg does. Thierry's stories of his exploits tracking zombies, humans who have lost their attachment to their loas and who are, therefore, devoid of affect, will, self-consciousness, and rationality, serve as a counterpoint to Grigg's professional accomplishments. His stories, as well as his 
efforts to release Grigg from his zombification through the water ritual, function as a critique of the Western modern subject, showing its portrayal of universal rationality to be illusory. Grigg's rejection of the ritual further indicates Grigg's refusal to remember the neocolonial bonds that bind together the history of his own country with that of Haiti that emerged as a legacy of the slave trade. He fails to remember that these very bonds later became explicitly manifested in the U.S. military occupation of Haiti from 1915 to 1934, and, eventually, in the ousting of Aristide toward the end of the century.

Grigg could hardly be aware, moreover, of how his own declarative rather than interrogative form of relating, a linguistic and social model that fits with his general view of reality, is continuous with Papa Doc Duvalier's noiriste ideology, which can be traced back to the U.S. occupation of Haiti. This political phase of Haitian history sparked widespread investigation into Haitian cultural identity, which Duvalier used to justify his repressive fourteen-year regime (1957-1971). According to the noiristes, Valerie Kaussen affirms, throughout history the mulatto ruling elite had persisted in imposing a European culture on its citizens (Kaussen 2005). The internalization of colonial relations caused by the legacy of enslavement and colonization had led to the incapability of the masses to transcend their history, causing them to remain in a state of constant regress, or in evolutionary terms, of atavism.

Whereas in evolutionary science atavism refers to a condition of physical resemblance to one's ancestors, Duvalier, himself a physician, applied the term in a socialDarwinian sense, incorporating definitions derived from vodou belief systems. He argued, along with his collaborator Lorimer Denis, that the regress, caused by the ancestral past, became materialized in the body of the Haitian people. In an article they wrote in 1939, Kaussen notes, Denis and Duvalier refer to the bodily substance causing such atavistic tendencies as magma: white genetic material introduced during contact with the Europeans (Kaussen 2005, 71). She further explains that according to Duvalier and the noiristes, the devolving tendencies in the Haitian people required the implementation of political models based on the master/slave relationship itself, but with a black class as master (73). Grigg's scientific modes of inquiry and practice are thus tied to modes of thought that have not only given rise to the repressive current regime, a social fact that he refuses to remember, but also cause him to further participate in such practices.

\section{The Reader and the Naturalist-Realist Reconstruction}

Grigg meets his end before examining his beliefs and practices against the background data of his social context, blindly accepting the scripted roles of gendered and raced dominance that have come not only to define him but also to entrap him. He disseminates falsified reports of his findings, remaining ignorant of how his own interests suppress the identities and attending interests of those closest to him: his wife, Thierry, and other Haitians who aid in his search for the elusive specimen. He implies that his actions are innocent and that his achievements are the result of his 
individual efforts; yet he not only intentionally conceals his interests, he also evades any accountability to the community upon which he has depended for his work. He is antithetical to Code's ecological subject, who understands that knowledge, conceived as a resource for survival, requires interdependence between distinct knowledge-seekers, and who "is self-critically cognizant of being part of the world, both social and natural, in which her knowings, feelings, and actings always produce effects, be they positive, negative, or indifferent" (Code 2003, 193).

Given Grigg's epistemological ignorance, the reader must stand in for him to revalorize his epistemic status and cultural identity, as well as those of Thierry and other Haitians that he encounters, by being attentive to the diverse responses of the characters to the events narrated. In their interaction with one another, the characters express a range of responses to dominant epistemic practices. These include Grigg's failure to understand the epistemic significance of identities as well as Thierry's openness to learn from Grigg's insights, but without allowing Grigg to exclude him as knowledge producer. Through her characters' actions and reactions, Montero foregrounds the erroneous nature of the assumptions informing the unarticulated metaphor, thereby creating an oppositional lens that allows the reader the ability to evaluate Grigg's distortive, neocolonizing logic and the background contexts that have shaped it.

As postpositivist realist literary theorist Paula Moya notes, interpretive errors and ideological mystifications are the result of race, class, gender, and national hierarchies that have been naturalized over time, distorting social reality (Moya 2002, 115-16). Interpretive errors can be illuminated most effectively in narratives in which subaltern subjects recount their efforts to push against dominant narratives of their identities. Rather than assimilating to hegemonic norms, which results in the diminishment of the epistemic resources derived from that identity, the character contests such norms in order to reclaim his or her historical identity (115-23). In discovering the character's struggles, the reader becomes engaged in a pedagogical process of ascertaining the more plausible "story" and in the process learns how social mystifications are fabricated, reproduced, and contested, as well as about his or her co-participation in such processes (129).

Montero does something a bit different: she invites the reader to participate in transformative knowledge practices in spite of her protagonist. She encourages the reader to learn and rehearse practices of knowing based not on Grigg's decontextualized propositional statements or unreflective obedience to mechanistic laws, but rather by learning about mystification and ignorance produced by one's social location and membership in a particular community. She also carefully recreates the interpretive context or horizon of understanding in order to aid the reader in assessing Grigg's epistemic reliability. Against Grigg's propositional understanding, Montero shows that people do not understand the world sentence by sentence, but rather, as cultural psychologist Jerome Bruner asserts, paragraph by paragraph, that is, through the relocation of events as well as human activities and practices within the larger social structures that provide the interpretive reference for the elements they encompass (Bruner 1990, 64). This nonpropositional understanding, as Ernesto Javier 
Martínez points out in his analysis of analogous interpersonal struggles in Baldwin's Another Country, is nonetheless difficult to achieve precisely because it requires epistemic complexity, requiring the enactment of important epistemic shifts, and raises "difficult questions regarding politics and objectivity" (Martínez 2009, 793). ${ }^{3}$ This type of knowledge-practice asks the reader/inquirer to detect new sets of relations that will foreground social features that have been obscured, thereby changing the inquirer's entire metaphorical understanding.

Through a reconstruction of the broader interpretive contexts, the reader is led to conclude that Grigg's and Patterson's choice to prioritize survival as their line of inquiry is caused less by their concern for human flourishing than by Patterson's fear of his imminent demise and by Grigg's fear of the extinguishing of his gendered dominance as a result of the competitive advances of his rival, Barbara. The reader is also led to assess Grigg's implementation of "objective" science in light of the activities of other knowers who bring a different set of theoretical presuppositions to the inquiry. In weighing the different presuppositions, the reader can trace the interests and power structures these meaning-making systems differently enlist and produce in order to determine the consequences of such interests and structures on what and who is claimed to be known.

Montero utilizes several frame-breaking mechanisms to dispel the illusion of coherence of Grigg's "narrative" and to help the reader reconnect the dots. These include: 1) ironic deployment of the survival of the fittest metaphor that redundantly signals Grigg's incapacity to "fit" into his environment and survive; 2) juxtaposition of Grigg's unreliable narration with Thierry's, fostering the reader's recognition of Grigg's irrational behavior; and 3) metalepsis, namely, references to real scientists, journals, and the real global extinction of frogs. Metalepsis, as Fludernik affirms, causes a transgression of narrative levels (Fludernik 2009, 100). I suggest that it also heightens the reader's sense of the real by separating the reader's illusion of autonomy from the struggles of the characters. Montero thereby encourages the reader to view Grigg's behavior as tied to the background assumptions of Western contemporary narratives that justify U.S. political interventions within foreign regions. ${ }^{4}$

Realist and naturalized epistemological conceptions of narrative knowing highlight how the contexts of discovery, that is, the experiences and background of the scientist that cause him to generate a problem or hypothesis, inform scientific modes of inquiry. When focusing on the context of discovery as much as the context of justification, as well as their interconnections, it becomes possible to better grasp the relationship between power and knowledge. As a case in point, the Anglo-American scientists' concealment of the contexts of discovery in Montero's work allows them to use their membership in a socially dominant group to invest their epistemological practices with universal significance while suppressing others that might be more necessary for human flourishing and survival. Montero uses the context-sensitive apparatus of narrative to demonstrate the fallibility of Grigg's solipsistic knowledgepractices. His method only serves to produce what Code refers to as an epistemological monoculture that develops both in the academy and in everyday life, suppressing 
those forms that depart from the stringent dictates of an exaggerated ideal of scientific knowledge-making (Code 2006, 8-9).

Realist and naturalized epistemological approaches to narrative, finally, encourage the reader to be reflective about his or her own investments in Grigg's metaphorical system and to reconsider Grigg's motivations, including his psychosocial needs, as well as the ideational complexes to which he is indebted, produced by scientists, educators, and statesmen since the latter part of the nineteenth century. By exposing the errors of these presuppositions, Montero offers epistemic access to features of the social world that might otherwise be obscured to her readers, due to their social location. She enjoins her readers to engage these complex questions from within that access point in order to develop socially engaged, transformative epistemic practices. She thus extends to readers a chance to emancipate themselves from the tyranny of invisible and therefore unassailable concepts that have given rise to the Euro-American reference group as the constitutive epistemic and political norm. Herein lies the significance of her axiological project, one that she undertakes in the name of a liberating Caribbean identity-formation.

\section{NOTES}

1. On feminist approaches using narrative, see Rooney 1996. For a review of literature on the narrative turn, see Krieswirth 2000.

2. For an analysis of vodou in Montero's novel, see Rivera 2002.

3. For other examples of analyses of epistemic struggles within literary texts, drawing from a naturalist-realist lens, see Butler 2006; Gillman 2010.

4. For an analysis of heredity in Caribbean narrative discourses, see Alcocer 2005.

\section{REFERENCES}

Alcocer, Rudyard J. 2005. Narrative mutations: Discourses of heredity and Caribbean literature. New York: Routledge.

Alcoff, Linda M. 1995. Is the feminist critique of reason rational? Philosophical Topics 23 (2): $1-25$.

Babbitt, Susan. 1993. Feminism and objective interests: The role of transformation experiences in rational deliberation. In Feminist epistemologies, eds. Linda Alcoff and Elizabeth Potter. New York: Routledge.

Benhabib, Seyla. 1992. Situating the self: Gender, community and postmodernism in contemporary ethics. New York: Routledge.

Bruner, Jerome. 1990. Acts of meaning. Cambridge, Mass.: Harvard University Press.

Butler, Johnella. 2006. African American literature and realist theory: Seeking the truetrue. In Identity politics reconsidered, eds. Linda M. Alcoff et al. New York: Palgrave Macmillan.

Code, Lorraine. 1993. Taking subjectivity into account. In Feminist epistemologies, ed. Linda Alcoff and Elizabeth Potter. New York: Routledge. 
- 1998. Voice and voicelessness: A modest proposal? In Philosophy in a feminist voice: Critiques and reconstructions, ed. Janet A. Kourany. Princeton: Princeton University Press.

- 2003. What is natural about epistemology naturalized? In Feminist interpretations of W. V. O. Quine, eds. Lynn Hankinson Nelson and Jack Nelson. University Park: Pennsylvania State University Press.

- 2006. Ecological thinking: The politics of epistemic location. New York: Oxford University Press.

Dayan, Joan. 1997. Vodoun, or the voice of the gods. In Sacred possessions: Vodou, Santería, Obeah, and the Caribbean, eds. Margarite Fernández Olmos and Lizabeth Paravisino-Gebert. New Brunswick, N.J.: Rutgers University Press.

Dunmire, Patricia, and David Kaufer. 1996. Irony. In Encyclopedia of rhetoric and composition: Communication from ancient times, ed. Theresa Enos. New York: Garland Press.

Farmer, Paul. 2003. The uses of Haiti. Monroe, Maine: The Common Courage Press.

Fernández Olmos, Margarite. 1997. Trans-Caribbean identity and the fictional world of Mayra Montero. In Sacred possessions: Vodou, Santería, Obeah, and the Caribbean, eds. Margarite Fernández Olmos and Lizabeth Paravisino-Gebert. New Brunswick, N.J.: Rutgers University Press.

Fludernik, Monika. 2009. An introduction to narratology. London: Routledge.

Gillman, Laura. 2010. Unassimilable feminisms: Reappraising feminist, womanist, and mestiza identity politics. New York: Palgrave Macmillan.

Hesse, Barnor. 2000. Un/settled multiculturalisms: Diasporas, entanglements, "transruptions". London: Zed Books.

Jaggar, Alison M. 1983. Feminist politics and human nature. Totowa, N.J.: Rowman and Allanheld Publishers.

Kaussen, Valerie. 2005. Race, nation, and the symbols of servitude in Haitian noirisme. In The masters and the slaves: Plantation relations and mestizaje in American imaginaries, ed. Alexandra Isfahani-Hammand. New York: Palgrave Macmillan.

Krieswirth, Martin. 2000. Merely telling stories?: Narrative and knowledge in the human sciences. Poetics Today 21 (2): 293-318.

Kuhn, Thomas S. 1996. The structure of scientific revolutions. 3rd ed. Chicago: University of Chicago Press.

Martínez, Ernesto Javier. 2009. Dying to know: Identity and self-knowledge in Baldwin's Another Country. PMLA 124 (3): 782-97.

Mohanty, Satya P. 2000. The epistemic status of cultural identity: On Beloved and the postcolonial condition. In Reclaiming identity: Realist theory and the predicament of postmodernism, eds. Paula M. L. Moya and Michael R. Hames-García. Berkeley: University of California Press.

Montero, Mayra. 1997. In the palm of darkness. New York: HarperCollins.

Moya, Paula M. L. 2002. Learning from experience: Minority identities, multicultural struggles. Berkeley: University of California Press.

Novoa, Adriana, and Alex Levine. 2010. Darwinism. In A companion to Latin American philosophy, eds. Susana Nuccetelli, Ofelia Schutte, and Natalia Bueno. Malden, Mass.: Wiley-Blackwell Publishers. 
Palmié, Stephan. 2002. Wizards and scientists: Explorations in Afro-Cuban modernity and tradition. Durham, N.C.: Duke University Press.

Richards, Judith. 2001. The struggle to naturalize literary studies: Chicana literary theory and analysis. In Engendering rationalities, eds. Nancy Tuana and Sandra Morgen. Albany: State University of New York Press.

Rivera, Angel A. 2002. Silence, voodoo, and Haiti in Mayra Montero's In the Palm of Darkness. http://www.lehman.cuny.edu/ciberletras/v04/Rivera.html (accessed June 4, 2012).

Rooney, Ellen. 1996. What's the story: Feminist theory, narrative address. Differences 8 (1): $1-30$.

Schiappa, Edward. 1993. Burkean tropes and Kuhnian science: A social constructionist perspective on language and reality. JAC 13 (2): 401-22.

Stepan, Nancy Leys. 1986. The role of analogy in science. Isis 77 (2): 261-77.

Stone-Mediatore, Shari. 2003. Reading across borders: Storytelling and knowledges of resistance. New York: Palgrave Macmillan.

Tanesini, Alessandra. 1999. An introduction to feminist epistemologies. Oxford: Blackwell Publishers. 